\title{
Bioleaching and toxicity of metallurgical wastes
}

\author{
Anna Potysz ${ }^{\mathrm{a}, *}$, Artur Pędziwiatr ${ }^{\mathrm{b}}$, Sebastian Hedwig ${ }^{\mathrm{c}}$, Markus Lenz $^{\mathrm{c}, \mathrm{d}}$ \\ ${ }^{\text {a }}$ University of Wroclaw, Institute of Geological Sciences, Cybulskiego 30, 50-205 Wroctaw, Poland \\ ${ }^{\mathrm{b}}$ Warsaw University of Life Sciences (WULS-SGGW), Institute of Agriculture, Nowoursynowska Str. 159/37, 02-787 Warsaw, Poland \\ ${ }^{\mathrm{c}}$ Institute for Ecopreneurship, School of Life Sciences, University of Applied Sciences and Arts Northwestern Switzerland, Switzerland \\ ${ }^{\mathrm{d}}$ Sub-Department of Environmental Technology, Wageningen University, 6700 AA, Wageningen, the Netherlands
}

\section{A R T I C L E I N F O}

\section{Editor: GL Dotto}

\section{Keywords:}

bioleaching

metals

copper slag

lead matte

toxicity

\begin{abstract}
A B S T R A C T
Metallurgical wastes contain metals that are unrecovered during industrial processing. The disposal of these wastes is technically difficult due to the potential release of metals through weathering. Therefore, alternative management methods are currently sought. The high leaching susceptibility of these wastes combined with the need for alternative sources of rare and critical metals creates a need for residual element recovery. This study evaluated the leaching potential of lead matte and copper slag through chemical mineral acid leaching as well as indirect bioleaching with organic acids and direct bioleaching using Acidithiobacillus thiooxidans. The leaching efficiency of these acids was compared based on different normality equivalents. Additionally, the effects of pulp density (1-10\%) and extraction time (24-48 h) were assessed. Slag toxicity was assessed with a germination test in concentrated and diluted leachates using Brassica juncea. The results demonstrated that copper slag is particularly suitable for chemical treatment because as much as $91 \mathrm{wt} . \% \mathrm{Cu}$ and $85 \mathrm{wt} . \% \mathrm{Zn}$ or $70 \mathrm{wt} . \% \mathrm{Cu}$ and 81 wt.\% Zn were extracted using $\mathrm{HNO}_{3}$ or bacterial leaching, respectively. The residual slag was characterized by significant metal depletion and the presence of gypsum, rendering it more suitable for further use or disposal. Lead matte released 65 wt.\% Cu and 8 wt.\% Zn using mineral acid leaching while 70 wt.\% Cu and 12 wt.\% Zn were released using bacterial leaching. Further process optimization is needed for lead matte to generate residue depletion in toxic metals. Toxicity assessment showed toxic characteristics in metal-loaded leachates originating from waste treatment that inhibited germination rates and root development.
\end{abstract}

\section{Introduction}

Various metallic elements and rare earth elements (REE) are indispensable for many products of modern society [1-3]. However, due to the intensive exploitation of natural ores, some reserves are already limited [4]. On the other hand, metal reserves may be replenished using secondary resources [5]. The search for secondary resources has became an urgent issue in the recent past [6-8]. For example, the European Commission has compiled a list of critical raw materials (with 27 currently listed), and its resource policy is more oriented towards recycling [9]; the "life cycle" of industrial materials should be extended so that disposal is no longer the "end-of-life."

Slags and mattes are good candidates for recovery due to their relatively high metal content [10]. In particular, environmentally benign methods such as biological leaching may offer net savings in terms of chemical and energy use in comparison to primary mining of base metals and REE [11]. Individual wastes are characterized by different chemical and phase (mineral) compositions [12], with each phase having a certain susceptibility to dissolution. Therefore, the specific phase that incorporates the majority of desired metal needs be recognized and targeted during leaching [13]. Most studies highlight the importance of good process control in order to gain the highest possible quantities of metals in a short time (i.e., to achieve high extraction rates). In particular, pulp density (PD) and fraction size are crucial because: i) lower PD means a higher quantity of reactants acting on the dissolution of the materials subjected to the process; and ii) a smaller fraction size means a greater exposure of each individual phase to the leaching solution [14]. Despite the high potential of these processes, there are still many technological obstacles to overcome prior to commercial metallurgical waste bioleaching.

In this regard, the aim of this study was: i) to investigate the technical feasibility of metal extraction from metallurgical wastes; ii) to optimize extraction conditions; iii) to generate a stable residue that is depleted in metals; and iv) to estimate the potential economic gains of element

\footnotetext{
* Corresponding author.

E-mail address: anna.potysz@uwr.edu.pl (A. Potysz).
} 
Table 1

Chemical and phase compositions of studied wastes

\begin{tabular}{|c|c|c|}
\hline Sample ID & $\mathrm{CS}$ & LM \\
\hline \multicolumn{3}{|c|}{ Major and minor elements (wt. \%) } \\
\hline $\mathrm{Si}$ & 15.4 & 0.7 \\
\hline $\mathrm{Ti}$ & 0.3 & 0.0 \\
\hline $\mathrm{Al}$ & 5.3 & 0.2 \\
\hline $\mathrm{Fe}$ & 11.5 & 31.2 \\
\hline Mn & 0.2 & 0.4 \\
\hline $\mathrm{Mg}$ & 3.4 & 0.1 \\
\hline $\mathrm{Ca}$ & 14.8 & 0.4 \\
\hline $\mathrm{Na}$ & 0.6 & 0.7 \\
\hline $\mathrm{K}$ & 2.5 & 0.8 \\
\hline S & $<0.02$ & 25.3 \\
\hline \multicolumn{3}{|c|}{ Minor elements ( $m g \mathrm{~kg}^{-1}$ ) } \\
\hline $\mathrm{Cu}$ & 31,870 & 36,050 \\
\hline $\mathrm{Pb}$ & 44,700 & 54,900 \\
\hline $\mathrm{Zn}$ & 15,100 & 199,600 \\
\hline Co & 1750 & 60.5 \\
\hline Mo & 721 & 348 \\
\hline $\mathrm{Cr}$ & 232.6 & 828 \\
\hline $\mathrm{Ni}$ & 691.3 & 441 \\
\hline \multicolumn{3}{|c|}{ Phase composition ++ major, + minor, $(+)$ traces } \\
\hline & $\begin{array}{l}\text { Glass }++ \\
\text { Metallic Cu-rich droplets }+\end{array}$ & $\begin{array}{l}\text { Sphalerite/Marmatite }(\mathrm{Zn}, \mathrm{Fe}) \mathrm{S}++ \\
\text { Pyrrhotite }\left(\mathrm{Fe}_{(\mathrm{x}-1)} \mathrm{S}\right)+ \\
\text { Bornite }\left(\mathrm{Cu}_{5} \mathrm{FeS}_{4}\right)+ \\
\text { Chalcopyrite }\left(\mathrm{CuFeS}_{2}\right)+ \\
\text { Fayalite }\left(\mathrm{Fe}^{2+}{ }_{2} \mathrm{SiO}_{4}\right)+ \\
\text { Glass }+\end{array}$ \\
\hline
\end{tabular}

++ major, + minor

*phase composition determined by XRD and microprobe analyser (see SI)

recovery. The extraction procedures were applied to two types of metallurgical wastes, granulated amorphous copper slag (CS) and massive crystalline lead matte (LM). The following parameters were evaluated: i) acid type $\left(\mathrm{H}_{2} \mathrm{SO}_{4}, \mathrm{HCl}, \mathrm{HNO}_{3}, \mathrm{C}_{6} \mathrm{H}_{8} \mathrm{O}_{7}\right.$, and $\left.\mathrm{H}_{2} \mathrm{C}_{2} \mathrm{O}_{4}\right)$; ii) $\mathrm{PD}$; iii) extraction time (up to $48 \mathrm{~h}$ ) for chemical leaching; and iv) PD (1\%, $5 \%, 10 \%)$ for bioleaching with Acidithiobacillus thiooxidans. In addition, leachate toxicity was assessed with germination tests using Brassica juncea exposed to concentrated and diluted leachates. The novelty of this study is that neither chemical leaching nor bioleaching of these specific wastes has been explored in detail. The main parameters of the value of optimization for prospective development of extraction at a larger scale are highlighted.

\section{Materials and methods}

\subsection{Materials}

Two types of metallurgical wastes, CS and LM, were selected for this study (Table 1; for detailed information concerning bulk properties, see [15]).

\subsection{Experimental procedures}

\subsubsection{Bioleaching experiments}

Bioleaching with $A$. thiooxidans (strain number DSM 9463, available from Deutsche Sammlung von Mikroorganismen und Zellkulturen; Braunschweig, Germany) was carried out on wastes using $1 \%, 5 \%$, and $10 \%$ pulp densities (PDs). Desired pulp densities were obtained by placement of $1 \mathrm{~g}, 5 \mathrm{~g}$ and $10 \mathrm{~g}$ of wastes respectively in $100 \mathrm{~mL}$ of solution. The growth medium (initial $\mathrm{pH}=2.5$ adjusted using $1 \mathrm{~N} \mathrm{H}_{2} \mathrm{SO}_{4}$ ) used for bioleaching was prepared according to recommendation of supplier (DSMZ Medium 670) and it composed of $2 \mathrm{~g}$ ammonium sulfate $\left(\left[\mathrm{NH}_{4}\right]_{2} \mathrm{SO}_{4}\right), 0.25 \mathrm{~g}$ magnesium sulfate $\left(\mathrm{MgSO}_{4} \times 7 \mathrm{H}_{2} \mathrm{O}\right), 0.1 \mathrm{~g}$ dipotassium hydrogen phosphate $\left(\mathrm{K}_{2} \mathrm{HPO}_{4}\right)$ and $0.1 \mathrm{~g}$ potassium chloride $(\mathrm{KCl})$ per $1 \mathrm{~L}$ of ultrapure water and adding $3 \mathrm{~g} / 100 \mathrm{~mL}$ of elemental sulfur. Amount of sulfur added to medium was higher (i.e. $3 \mathrm{~g} / 100 \mathrm{~mL}$ ) than that recommended by supplier (i.e. $0.5 \mathrm{~g} / 100 \mathrm{~mL}$ ). The reason for choice of a higher sulfur supplementation was to improve extraction efficiency. According to literature reports, it has been proven that increase of supplementation to a value higher than $0.5 \mathrm{~g} / 100 \mathrm{~mL}$ positively affect bioleaching [16].

All the materials (slags, glassware and solutions) were sterilized at $121{ }^{\circ} \mathrm{C}$ for 20 minutes prior to the experiment. The incubation Erlenmeyer flasks were placed in an incubator shaker $(100 \mathrm{rpm})$ at $30{ }^{\circ} \mathrm{C}$ (Biosan shaker incubator ES-20/60), and the $1 \mathrm{~mL}$ leachate was sampled under sterile conditions after 10,20, and 30 days. This sampling interval was selected based on preliminary studies indicating a time of 2-3 weeks is needed for $\mathrm{pH}$ decline in the incubations.

\subsubsection{Chemical leaching}

In addition to the biotic experiments, metallurgical wastes were also subjected to extraction with various mineral and organic acids. The first set of treatments was carried out with $\mathrm{H}_{2} \mathrm{SO}_{4}$ at different acid concentrations $\left(0.1 \mathrm{~mol} \mathrm{~L}^{-1}, 0.5 \mathrm{~mol} \mathrm{~L}^{-1}\right.$, and $\left.1 \mathrm{~mol} \mathrm{~L}^{-1}\right)$, pulp density (PD $1 \%$, $5 \%$, and $10 \%$ ), and extraction time ( 24 and $48 \mathrm{~h}$ ). The $\mathrm{H}_{2} \mathrm{SO}_{4}$ leaching solutions were prepared by dissolving appropriate amount of stock solution (95 wt. $\% \mathrm{H}_{2} \mathrm{SO}_{4}$ analytical grade Chempur Poland) in $1 \mathrm{~L}$ of ultrapure water. The extraction time ( 24 and $48 \mathrm{~h}$ ) were chosen based on literature stating either $24 \mathrm{~h}$ as optimal [17-19] or applying higher temperatures to accelerate extraction [20] and references therein]. Instead of increasing temperature, here extraction time was elongated to $48 \mathrm{~h}$.

The waste fraction used for the screening experiments was $0.25-0.5$ $\mathrm{mm}$. The experiments were performed in a polypropylene flask placed in a horizontal shaker (150 rpm).

Additionally, mineral $\left(\mathrm{H}_{2} \mathrm{SO}_{4}, \mathrm{HCl}\right.$, and $\left.\mathrm{HNO}_{3}\right)$ as well as organic acids (citric acid and oxalic acid) were used at equimolar $(2 \mathrm{~N})$ concentration. All the reagents were analytical grade. Acids were supplied by Chempur Poland ( 95 wt.\% $\mathrm{H}_{2} \mathrm{SO}_{4}$ stock solution and $37 \mathrm{wt} . \% \mathrm{HCl}$ stock solution) and Merck (65 wt.\% $\mathrm{HNO}_{3}$ stock solution, citric and oxalic acids).

All chemical and bioleaching experiments were carried out in duplicate. The leachates were filtered using $0.45 \mu \mathrm{m}$ polytetrafluoroethylene syringe filters (for chemical treatments) and $0.22 \mu \mathrm{m}$ polytetrafluoroethylene syringe filters (for bioleaching teratments), acidified using $2 \%$ volume Suprapur $65 \mathrm{wt} . \% \mathrm{HNO}_{3}$ (Merck) and stored at $4{ }^{\circ} \mathrm{C}$ until the ICP-QQQ MS analysis. The data acquired through ICP MS were recalculated to express them as $\mathrm{mg} \mathrm{kg}^{-1}$ of the element released from each waste and to reveal the extraction efficiency (expressed as a percentage of the total). The liquid to solid ratio applied was then used to calculate metal leached from slags (in $\mathrm{mg} \mathrm{kg}^{-1}$ ). These were used to calculate relative amounts of element leached from slags (in wt.\%).

\subsubsection{Toxicity study}

Germination tests were used to assess the potential environmental toxicity of weathered/leached wastes. Seed germination is a crucial stage in plant development, wherefore seed germination and root elongation tests under exposure to metals provide a quick and reliable assessment of inhibition [21]. Usual application of such tests aims to select suitable plant for remediation of polluted areas [22], however we found it suitable to apply this tool to evaluate leachate toxicity [23] since potential leakage of mine drainage waters is observed worldwide [24,25].

B. juncea seeds were surface-sterilized using $5 \mathrm{wt} \% \mathrm{NaClO}$ (5 minutes immersion), rinsed 3 times with demineralized water, and then treated with the following metal-charged solutions after 30 days of leaching: LM-B (biotic leachate originating from lead matte treatment) and CS-B (biotic leachate originating from granulated slag treatment) as well as the abiotic solutions LM-C (chemical, abiotic leachate originating from lead matte treatment) and CS-C (chemical, abiotic leachate originating from granulated slag treatment). All leachates were applied undiluted and diluted (10x and 100x) using demineralized water. These experiments were accompanied by a procedural blank with $\mathrm{H}_{2} \mathrm{O}$ in order 

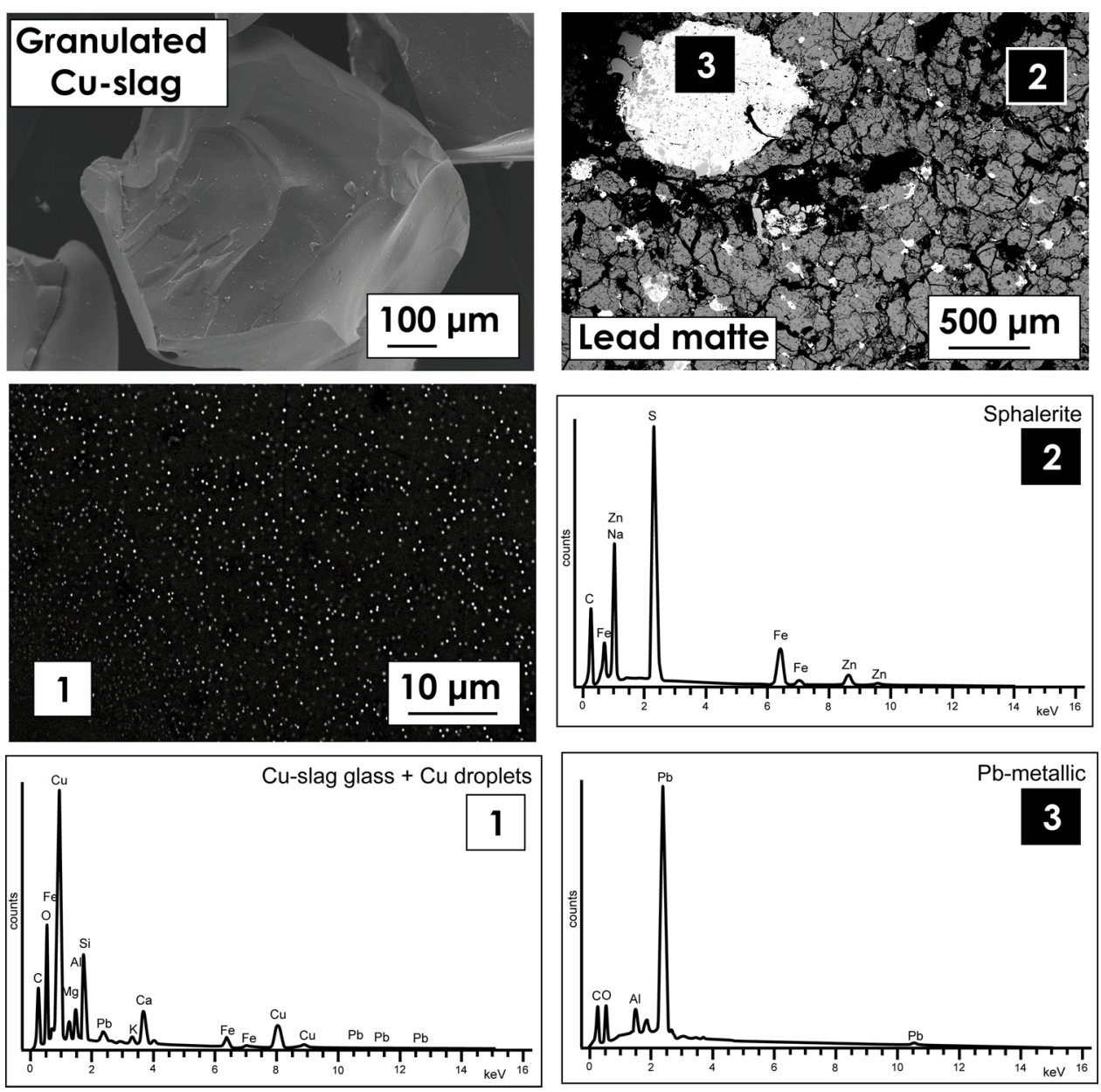

Fig. 1. Representative microphotographs of studied wastes.

to confirm the quality of the seeds was sufficient for use in the germination test, and controls using medium (C) and medium inoculated with bacteria (B) A. thiooxidans with the same dilutions used for the leachates. The seeds were sown in Petri dishes lined with filter paper, with 30 seeds per dish and 60 seeds per treatment (experiment carried out in duplicate), for a total 720 seeds. The seeds were immersed in $8 \mathrm{~mL}$ of a metalcharged leaching solution ( $\mathrm{C}$ or $\mathrm{B}$ ) and kept for 5 days in darkness at 22 ${ }^{\circ} \mathrm{C}$. The length of the roots was determined to a precision of $+/-1 \mathrm{~mm}$.

\subsection{Analytical measurements}

\subsubsection{Solution chemistry}

The leachates were analyzed using triple quadrupole inductively coupled plasma mass spectrometry (ICP-QQQ MS). The analysis was performed on an 8800 ICP-QQQ MS system (Agilent, Basel, Switzerland) using the general purpose operational settings. Quantification was performed via multi-element standards (Sigma-Aldrich). Rh was used as an internal standard to account for matrix effects. To quantify ${ }^{63} \mathrm{Cu}^{+}$and ${ }^{66} \mathrm{Zn}^{+}$, the ICP-MS system was operated in single-quad mode using helium as the collision gas.

\subsubsection{Characterization of solid samples}

The fresh LM and CS as well as the residues resulting from the leaching experiments were observed using scanning electron microscopy (SEM, JEOL JSM-IT100; acceleration voltage 15-20 kV) coupled with energy dispersive spectroscopy (EDS). The grains were gently rinsed with ultrapure water and dried at room temperature. The grains were then placed on a conductive tape and coated with carbon. For X-ray powder diffraction (XRD), fresh slags as well as leaching residues were milled using Mixer/Mill 8000M-Spex Sample Prep (Artisan, USA) or in agate mortar. XRD was carried out on a Bruker AXS D5005 diffractometer with a Kristalloflex ${ }^{\circledR} 760 \mathrm{X}$-ray generator (CoK $\alpha$ radiation, 40 $\mathrm{kV}$ voltage and $35 \mathrm{~mA}$ current). Accounting time was $1 \mathrm{~s}$ for each $0.02^{\circ}$ step (range of angles: $3^{\circ}$ to $70^{\circ} 2 \theta$ ). Due to the small amount of residue, a dedicated holder was filled with amorphous glass, with the sample placed on top. XRD confirmed the lack of crystalline phases in the glass used. The phases were identified based on the PDF-2 database (International Centre for Diffraction Data, 2020).

\section{Results and discussion}

\subsection{Composition of studied wastes}

The waste materials exhibited different chemical and phase compositions, and therefore their leaching behavior was also expected to differ. The CS was mainly composed of Si (15.4 wt.\%). The base metals of interest $(\mathrm{Cu}, \mathrm{Zn}$, and $\mathrm{Pb})$ were present at concentrations ranging from $1.5-4.5 \mathrm{wt} . \%$. The phase composition of this slag was dominated by the presence of glass and evenly distributed copper droplets, as indicated by SEM-EDS (Figs. 1 and S1, supplementary materials). However, no crystalline (X-ray diffracting) copper-bearing phase was found (Figure S1, supplementary materials). The LM was a divergent sample, characterized by a high Fe and S content reaching 31.2 wt.\% and 25.3 wt.\%, respectively. The presence of sphalerite (Figs. 1 and S1, supplementary materials) also suggests the other $S$ phases were sulfides (Table 1), in accordance with previous research [15]. 

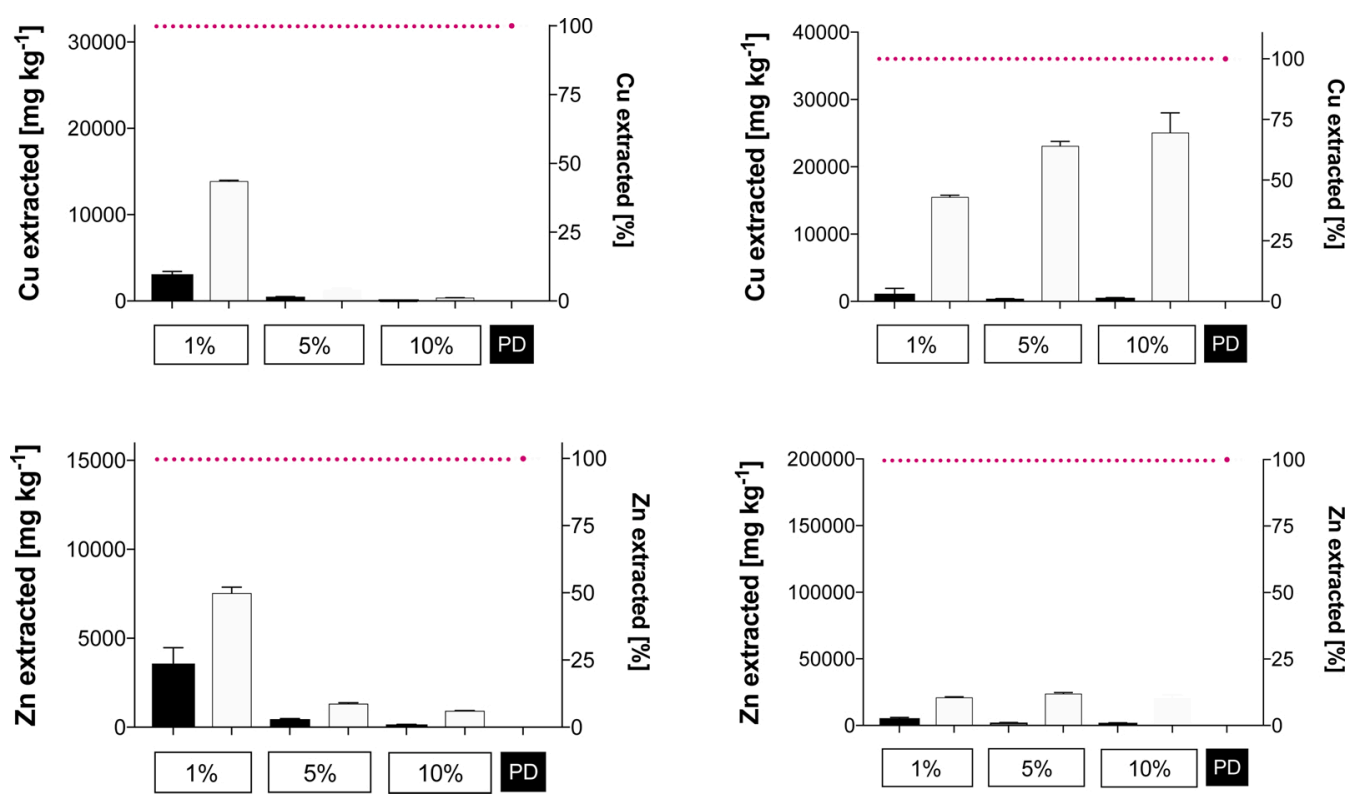

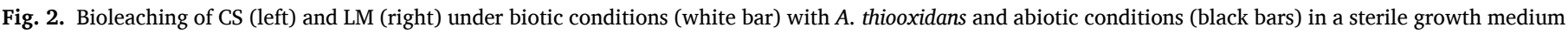
over 30 days; the dashed lines represent the bulk metal contents.

\subsection{Metal leaching by $A$. thiooxidans}

This study demonstrated that bacteria had a positive impact and notably improved metal extraction compared to abiotic conditions (Fig. 2). The bioleaching improved $\mathrm{Cu}$ and $\mathrm{Zn}$ extraction respectively by factors up to 62 and 11 in the case of LM and a factor up to 6 for CS. The activity of the bacteria used relies on the production of sulfuric acid as the result of elemental sulfur oxidation. Sulfide-bearing minerals contained in LM can serve as a source of sulfur for microorganisms [26]; however, a preferential use of external elemental sulfur can be expected.

Supplementation of elemental sulfur for bacteria can enhance leaching efficiency [27] although there may be limits to this [16]. Here, PD 1\% accounted for the highest efficiency for the CS material and reached $70.3 \mathrm{wt} . \%\left(22,417 \mathrm{mg} \mathrm{kg}^{-1}\right)$ and $80.6 \mathrm{wt} . \%\left(12,167 \mathrm{mg} \mathrm{kg}^{-1}\right)$ for $\mathrm{Cu}$ and $\mathrm{Zn}$, respectively (Fig. 2). Other treatments (PD 5\% and 10\%) accounted for much lower efficiencies (not more than $9 \mathrm{wt} . \%$ ). This can be attributed either to incomplete $\mathrm{S}$ oxidation (due to inhibition) or the buffering capacity of the wastes. A pH of 0.6 observed in PD $1 \%$ was close to the stochiometric amounts of $\mathrm{H}_{2} \mathrm{SO}_{4}$ formed ( $\mathrm{pH} 0.03$ at $3 \mathrm{~g} / 100$ $\mathrm{mL} \mathrm{S}$ ), and both PD 5\% and PD 10\% showed higher $\mathrm{pH}$ values (4.6 and 3.6, respectively). Previously, it has been demonstrated that larger fractions exhibit lower buffering potential, and metals can thus be more efficiently dissolved as compared to fine fractions $(<0.3 \mathrm{~mm})$ [28], which is in accordance with the current study. Another study using different $\mathrm{Cu}$ slags with amorphous structure found only $10 \mathrm{wt} . \%$ of $\mathrm{Cu}$ extractable at PD 5\% despite reaching a lower $\mathrm{pH}$ value $(0.98)$, underlining the good leachability of the wastes studied here. This can be attributed to the fact that $\mathrm{Cu}$ droplets as the main $\mathrm{Cu}$ carriers may be prone to dissolution.

Surprisingly, an opposite trend in efficiency was observed for LM, where the highest biotic extraction was achieved for PD 10\% reaching $69.6 \mathrm{wt} . \%\left(25,077 \mathrm{mg} \mathrm{kg}^{-1}\right)$ and $10.3 \mathrm{wt} \%$ (20476 mg kg$\left.{ }^{-1}\right)$, for $\mathrm{Cu}$ and $\mathrm{Zn}$, respectively. The final $\mathrm{pH}$ of the leachate was 0.9 (PD 10\%), indicating that sulfur oxidation was still incomplete. Extraction carried out at PD 1\% (pH 0.5) accounted for the release of only $43 \mathrm{wt} . \%(15,520 \mathrm{mg}$ $\left.\mathrm{kg}^{-1}\right)$ and $10.6 \mathrm{wt} . \%\left(21,162 \mathrm{mg} \mathrm{kg}^{-1}\right)$ for $\mathrm{Cu}$ and $\mathrm{Zn}$, respectively (Fig. 2).

The different behaviors of CS and LM in the bioleaching system are associated with: i) the different chemistry of these wastes and their different buffering capacities; ii) the susceptibility of $\mathrm{Cu}$ and $\mathrm{Zn}$-bearing phases present in these wastes; and iii) the time necessary for the dissolution of individual phases. LM's susceptibility to bioleaching at PDs $5 \%$ and $10 \%$ was higher compared to that observed for CS. Presumably, a higher Si content in CS accounted for a stronger buffering potential compared to LM, revealing the potential to produce acid due to the presence of sulfides in high volumetric proportions [29,30]. This high bioleaching potential of LM is an important finding because LM has previously been known for its high resistance to metal liberation using chemical treatment. Presumably, bacteria can dissolve $\mathrm{Cu}$ but not $\mathrm{Zn}$ sulfides, indicated by $\mathrm{ZnS}$ (sphalerite) remaining in the residues after extraction (Figure S1, supplementary materials). Bacteria enhanced $\mathrm{Cu}$ dissolution compared to chemical leaching (see below), possibly due to a longer duration of bioleaching. This indicates that the time needed for oxidation may limit process efficiency at ambient temperature [31]. Additionally, Cu-sulfides being a donor phases of $\mathrm{Cu}$ liberated into solution were well encapsulated between the crystals of fayalite. The latter is known for its relative resistance to dissolution. Thus, either strong acids in the case of chemical leaching or long-term bacterial activity are required in order to access these $\mathrm{Cu}$ donor phases. A low leachability of $\mathrm{Zn}$ during chemical extraction is due to its incorporation in Zn-sulfide which requires strong acids for dissolution. In contrast, relatively low solubility of $\mathrm{Zn}$ under bioleaching conditions can be caused by surface passivation by $S$ [32].

An analysis of leached residue originating from biotic and abiotic treatments revealed that pronounced differences in the characteristics of CS can be observed after bioleaching at PD 1\%. A clear occurrence of gypsum was indicated by the XRD patterns (Figure S1, supplementary materials). A similar characteristic of this material was observed for a buffer alone (containing sulfate). This indicates that leaching CS with a sulfate containing a microbial medium (or $\mathrm{H}_{2} \mathrm{SO}_{4}$ formed upon sulfide oxidation, see below) may be beneficial in yielding a metal-depleted, solid residue with lower environmental risk than untreated slags.

The $\mathrm{pH}$ plays an important role in bioleaching with $A$. thiooxidans. Upon oxidation of elemental sulfur $\mathrm{H}_{2} \mathrm{SO}_{4}$ is generated, acidifying the medium. Acidity in turn is one of the major factors influencing extraction yields. This study demonstrated that $\mathrm{pH}$ decrease under biotic conditions varied from one waste to another and it was highly dependent on pulp density, in particular in the case of CS. The lowest $\mathrm{pH}$ of 0.5 was obtained for LM incubated at $1 \% \mathrm{PD}$, whereas $\mathrm{pH}$ values observed at higher PDs were slightly higher (0.7 and 0.9 for PDs $5 \%$ and $10 \%$, 

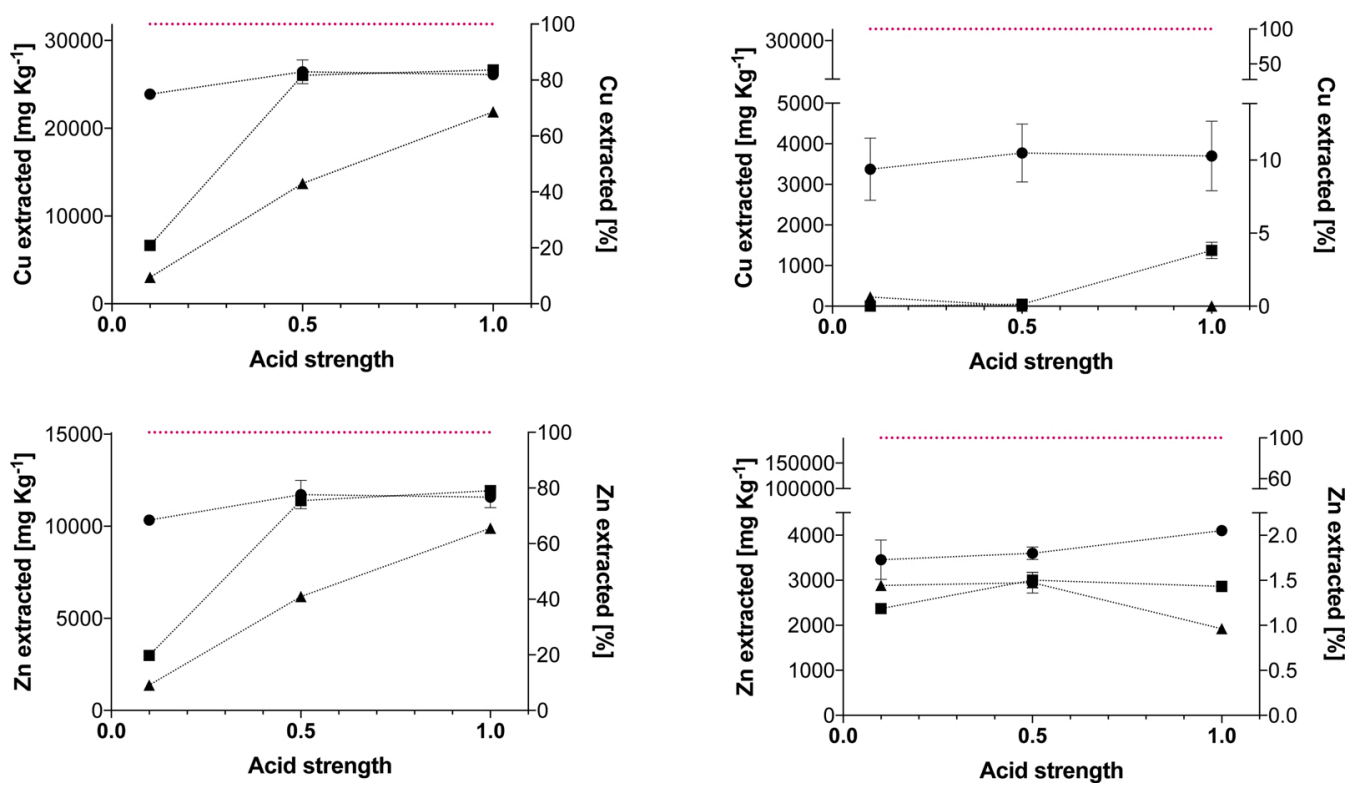

Fig. 3. Efficiency of $\mathrm{H}_{2} \mathrm{SO}_{4}$ with respect to $\mathrm{Cu}$ and $\mathrm{Zn}$ release at PD 1\% (circles), 5\% (squares), and 10\% (triangles) after $24 \mathrm{~h}$ treatment of $\mathrm{CS}$ (left) and LM (right); the dashed lines represent the bulk metal contents.

respectively). In contrast, $\mathrm{pH}$ values in $\mathrm{CS}$ incubations were higher (minimal 0.6 at PD 1\%, between 3.1-3.8 at higher PDs). As pointed out, CS is an amorphous material abound of glass, whereas LM is a sulfide rich material. Taking into account that both wastes were incubated under the same conditions it may be concluded that dissolution of CS included buffering reactions (Eq. 1-2) and counteracted bacterial acidification, while sulfides in LM are known for their acid producing potential and promoted acidification process in addition to fed elemental $\mathrm{S}$
(Eq. 3).

$$
\begin{aligned}
& -\mathrm{Si}-\mathrm{O}-\mathrm{M}_{\text {(glass) }}+\mathrm{H}^{+}=\mathrm{Si}-\mathrm{OH}_{\text {(glass) }}+\mathrm{M}^{+}{ }_{\text {(aq) }} \\
& \mathrm{Si}-\mathrm{O}-\mathrm{Si}+\mathrm{H}_{2} \mathrm{O}=-\mathrm{Si}-\mathrm{OH}+-\mathrm{Si}-\mathrm{OHEq} . \\
& \mathrm{MS}_{2}+7 / 2 \mathrm{O}_{2}+\mathrm{H}_{2} \mathrm{O}=\mathrm{M}^{2+}+2 \mathrm{SO}_{4}^{2-}+2 \mathrm{H}^{+} \text {Eq. }
\end{aligned}
$$

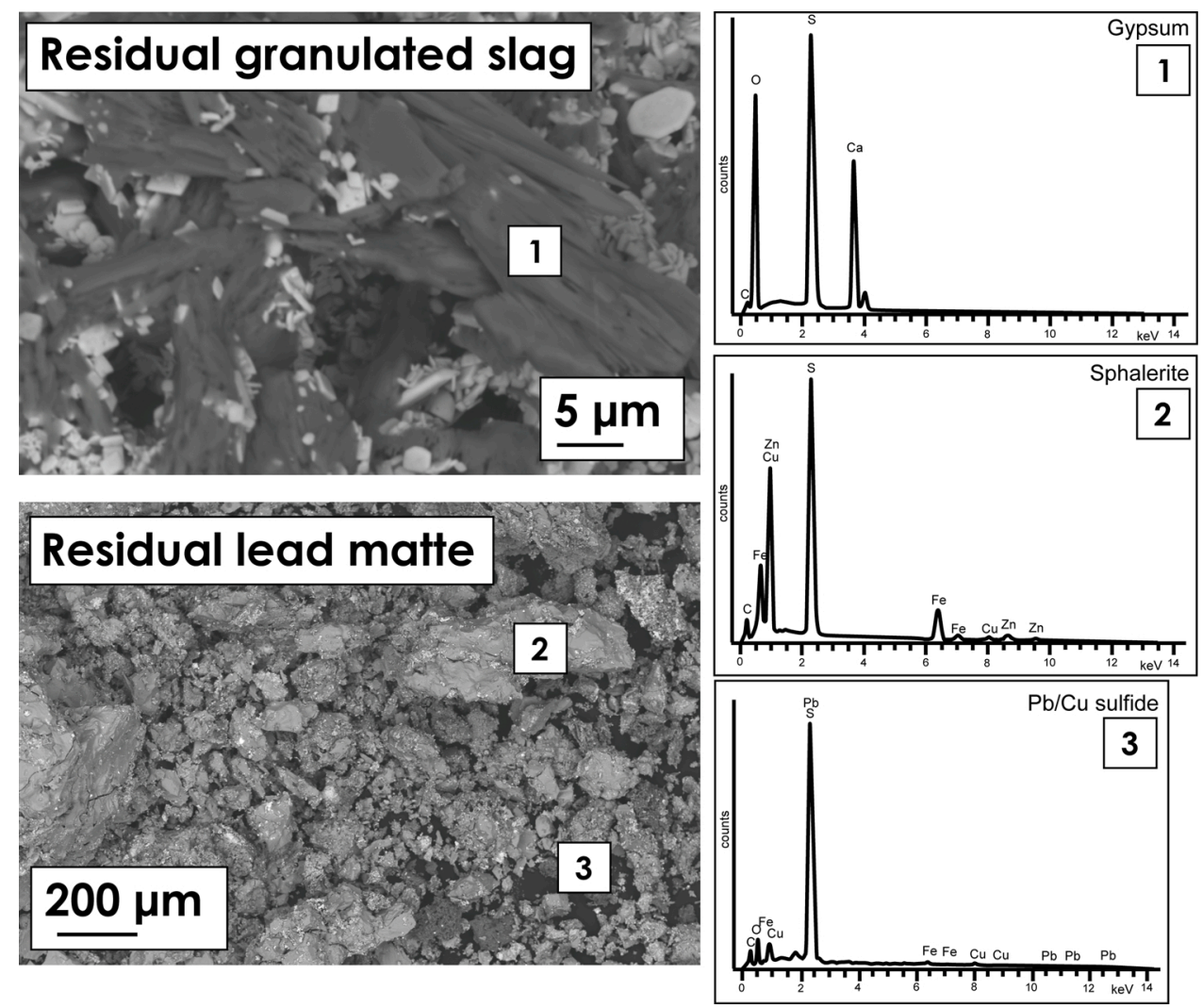

Fig. 4. SEM Images of metallurgical waste residues after chemical treatment. 

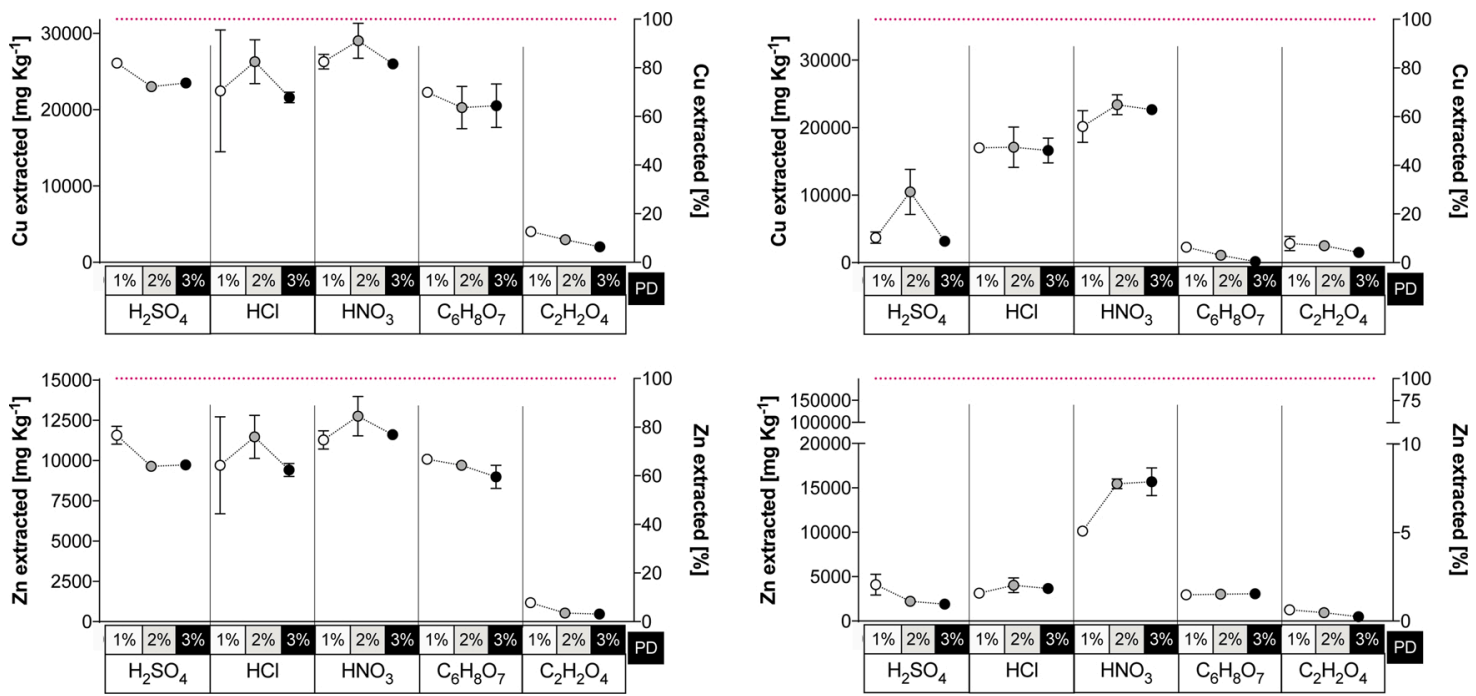

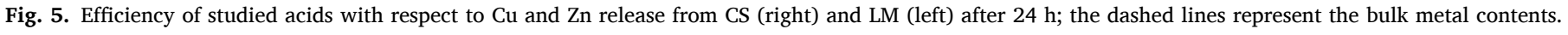

\subsection{Effect of $\mathrm{H}_{2} \mathrm{SO}_{4}$ concentration and pulp density on extraction yield}

Sulfuric acid $\left(\mathrm{H}_{2} \mathrm{SO}_{4}\right)$ has been used as an extracting agent (Fig. 3) since it has already been proven to extract metals well from various industrial wastes through proton-mediated dissolution [33-35]. The susceptibility to leaching is governed by: i) the susceptibility of individual phases to dissolution; and ii) the type of extracting agent [36,37]; therefore, different leaching trends were observed for CS and LM.

Importantly, $\mathrm{Cu}$ and $\mathrm{Zn}$ extraction from $\mathrm{CS}$ increased along with the increase in $\mathrm{H}_{2} \mathrm{SO}_{4}$ concentration. In particular, an increase in acid strength played a role at PD $10 \%$, reaching up to $21,868 \mathrm{mg} \mathrm{kg}^{-1}$ (68.6 wt.\%) of $\mathrm{Cu}$ and 9,896 mg kg${ }^{-1}$ (65.5 wt.\%) of Zn, with $1 \mathrm{~mol} \mathrm{~L}^{-1} \mathrm{H}_{2} \mathrm{SO}_{4}$. At PD 1\%, acid strength played a minor role whereas at PD 5\%, a notable increase in $\mathrm{Cu}$ and $\mathrm{Zn}$ extraction from $\mathrm{CS}$ was observed when the acid concentration increased from $0.1 \mathrm{~mol} \mathrm{~L}^{-1}$ to $0.5 \mathrm{~mol} \mathrm{~L}^{-1}$ (Fig. 3).

The experiment with $\mathrm{H}_{2} \mathrm{SO}_{4}(0.1 \mathrm{M}-1 \mathrm{M})$ revealed that $\mathrm{Cu}$ extraction from LM was relatively efficient only at PD 1\%; however, it was less dependent on the acid concentration. For all acid strengths $(0.1 \mathrm{M}-1 \mathrm{M})$ used at PD 1\%, Cu extraction was 3,376-3,772 $\mathrm{mg} \mathrm{kg}^{-1}$ (up to $10.5 \mathrm{wt}$. \%). In contrast, bioleaching at PD $1 \%\left(3 \mathrm{~g} / 100 \mathrm{~mL} \mathrm{~S}, 0.9 \mathrm{~mol} \mathrm{~L}^{-1} \mathrm{H}_{2} \mathrm{SO}_{4}\right)$ resulted in a release of $15,520 \mathrm{mg} \mathrm{kg}^{-1}$ (43.1 wt.\%), or $32.6 \mathrm{wt} . \%$ higher relative to nearly the same chemical conditions (i.e., $1 \mathrm{~mol} \mathrm{~L}^{-1} \mathrm{H}_{2} \mathrm{SO}_{4}$, $\mathrm{PD}$ $1 \%)$. The $\mathrm{Zn}$ extraction from LM was only slightly affected by acid strength and PD, reaching a maximum of $4,100 \mathrm{mg} \mathrm{kg}^{-1}(2.1 \mathrm{wt} . \%)$ at 1 $\mathrm{mol} \mathrm{L}^{-1}$ and PD 1\% while bioleaching resulted in the release of 21,162 $\mathrm{mg} \mathrm{kg}^{-1}$ (10.6 wt.\%), or $8.5 \mathrm{wt} \%$ higher relative to the chemical conditions.

Furthermore, the importance of a metal's association with a specific phase can be seen from trends in $\mathrm{Zn}$ behavior. Zn-bearing sphalerite is an omnipresent phase in LM, therefore the PD parameter did not play a role, and a longer leaching time may be required for improved sphalerite dissolution and subsequent $\mathrm{Zn}$ passage to the leachate [31]. In contrast, Zn leachability from CS was highly PD dependent, likely because Zn release takes place not only from glass, but also from $\mathrm{Cu}$ droplets merged with glass.

According to the SEM observations, CS residues from chemical and bioleaching contained newly formed gypsum (Fig. 4). It was depleted in the metals (Figure S1, supplementary materials) as opposed to the LM, which remained enriched in metals and was composed of the same phases detected in the fresh material. Therefore, one may expect environmentally more benign residues from CS.
Table 2

Comparison of treatment efficiencies obtained in this study with efficiencies obtained in few other works.

\begin{tabular}{|c|c|c|c|}
\hline \multicolumn{4}{|c|}{ Chemical treatment } \\
\hline $\begin{array}{l}\text { Waste } \\
\text { treated }\end{array}$ & Treatment conditions & $\begin{array}{l}\text { Results } \\
\text { [wt.\%] }\end{array}$ & Reference \\
\hline CS & $\mathrm{HNO}_{3}, \mathrm{PD} 2 \%$, t: $24 \mathrm{~h}$ & $\begin{array}{l}\mathrm{Cu}: 91 \\
\mathrm{Zn}: 85\end{array}$ & This study \\
\hline LS & $\mathrm{HNO}_{3}, \mathrm{PD} 2 \%, \mathrm{t:} 24 \mathrm{~h}$ & $\begin{array}{l}\text { Cu: } 65 \\
\mathrm{Zn}: 8\end{array}$ & This study \\
\hline Cu slag & $\begin{array}{l}0.35 \mathrm{~N} \mathrm{H}_{2} \mathrm{SO}_{4}, \mathrm{PD} 10 \%, \mathrm{t}: 4 \mathrm{~h}+\text { heat }+ \\
\mathrm{O}_{2} \text { pressure }\end{array}$ & $\mathrm{Cu} 92$ & [40] \\
\hline Cu slag & $12 \mathrm{~mol} \mathrm{~L}^{-1} \mathrm{HCl}, \mathrm{PD} 12.5 \%$, t: $12 \mathrm{~h}$ & $\begin{array}{l}\text { Cu } 33 \\
\text { Zn } 43\end{array}$ & {$[18]$} \\
\hline Cu slag & $4 \mathrm{~mol} \mathrm{~L}^{-1} \mathrm{H}_{2} \mathrm{SO}_{4}$, PD $12.5 \%$, t: $12 \mathrm{~h}$ & $\begin{array}{l}\mathrm{Cu} 55 \\
\mathrm{Zn} 65\end{array}$ & [18] \\
\hline Cu slag & $\begin{array}{l}0.4 \mathrm{~mol} \mathrm{~L}^{-1} \mathrm{H}_{2} \mathrm{SO}_{4}, \mathrm{PD} 10 \% \text {, t: } 0.66 \mathrm{~h}+ \\
\mathrm{O}_{2} \text { pressure }+ \text { heat }\end{array}$ & $\mathrm{Cu} 100$ & [41] \\
\hline Cu slag & $\begin{array}{l}2 \mathrm{~mol} \mathrm{~L}^{-1} \mathrm{H}_{2} \mathrm{SO}_{4}, \mathrm{PD} 1 \%, \mathrm{t}: 1 \mathrm{~h}+\mathrm{O}_{2} \\
\text { pressure }\end{array}$ & $\mathrm{Cu} 700$ & [42] \\
\hline Cu slag & $2 \mathrm{~mol} \mathrm{~L}^{-1} \mathrm{HCl}, \mathrm{PD} 1 \%, \mathrm{t}: 24 \mathrm{~h}$ & $\begin{array}{l}\mathrm{Cu} 30.5- \\
98.8 \\
\mathrm{Zn} 70-80\end{array}$ & [43] \\
\hline \multicolumn{4}{|c|}{ Bioleaching with A. thioxidans } \\
\hline $\begin{array}{l}\text { Waste } \\
\text { treated }\end{array}$ & Treatment conditions & $\begin{array}{l}\text { Results } \\
\text { [wt.\%] }\end{array}$ & Reference \\
\hline CS & PD $1 \%, \mathrm{t}: 30$ days & $\begin{array}{l}\mathrm{Cu}: 70 \\
\mathrm{Zn}: 81\end{array}$ & This study \\
\hline LS & $\begin{array}{l}\text { PD } 10 \%, \mathrm{t}: 30 \text { days } \\
\text { PD: } 5 \%, \mathrm{t}: 30 \text { days }\end{array}$ & $\begin{array}{l}\mathrm{Cu}: 70 \\
\mathrm{Zn}: 12\end{array}$ & This study \\
\hline $\mathrm{Pb} /$ Zn slag & PD $10 \%$, t: 9 days & $\mathrm{Zn}:>80$ & [44] \\
\hline Cu slag & $\begin{array}{l}\text { PD } \%, t: 12 \text { days } \\
\text { PD } 1 \%, t: 21 \text { days }\end{array}$ & Cu: 96.6 & [45] \\
\hline Cu slag & PD $10 \%, \mathrm{t}: 25$ days & $\begin{array}{l}\mathrm{Cu} 83 \\
\mathrm{Zn} 14\end{array}$ & [46] \\
\hline Cu slag & PD 2\%, t: 51 days & $\begin{array}{l}\text { Cu } 91 \\
\text { Zn } 23\end{array}$ & [47] \\
\hline Cu slag & PD 5\%, t: 80 days & $\mathrm{Cu} 700$ & [48] \\
\hline Cu slag & PD $7 \%, \mathrm{t}: 12$ days & $\mathrm{Cu} 70-100$ & {$[45]$} \\
\hline Cu slag & PD $1 \%, \mathrm{t}: 21$ days & Cu 52-99 & [43] \\
\hline
\end{tabular}

Abbreviations: PD (pulp density), t (treatment time)

\subsection{Efficiency of element extraction with equi-normal mineral and organic acids}

Various equi-normal mineral and organic acids were studied, and mineral acids were shown to be more efficient for $\mathrm{Cu}$ extraction from LM compared to organic agents (Fig. 5). Extraction with mineral acids 


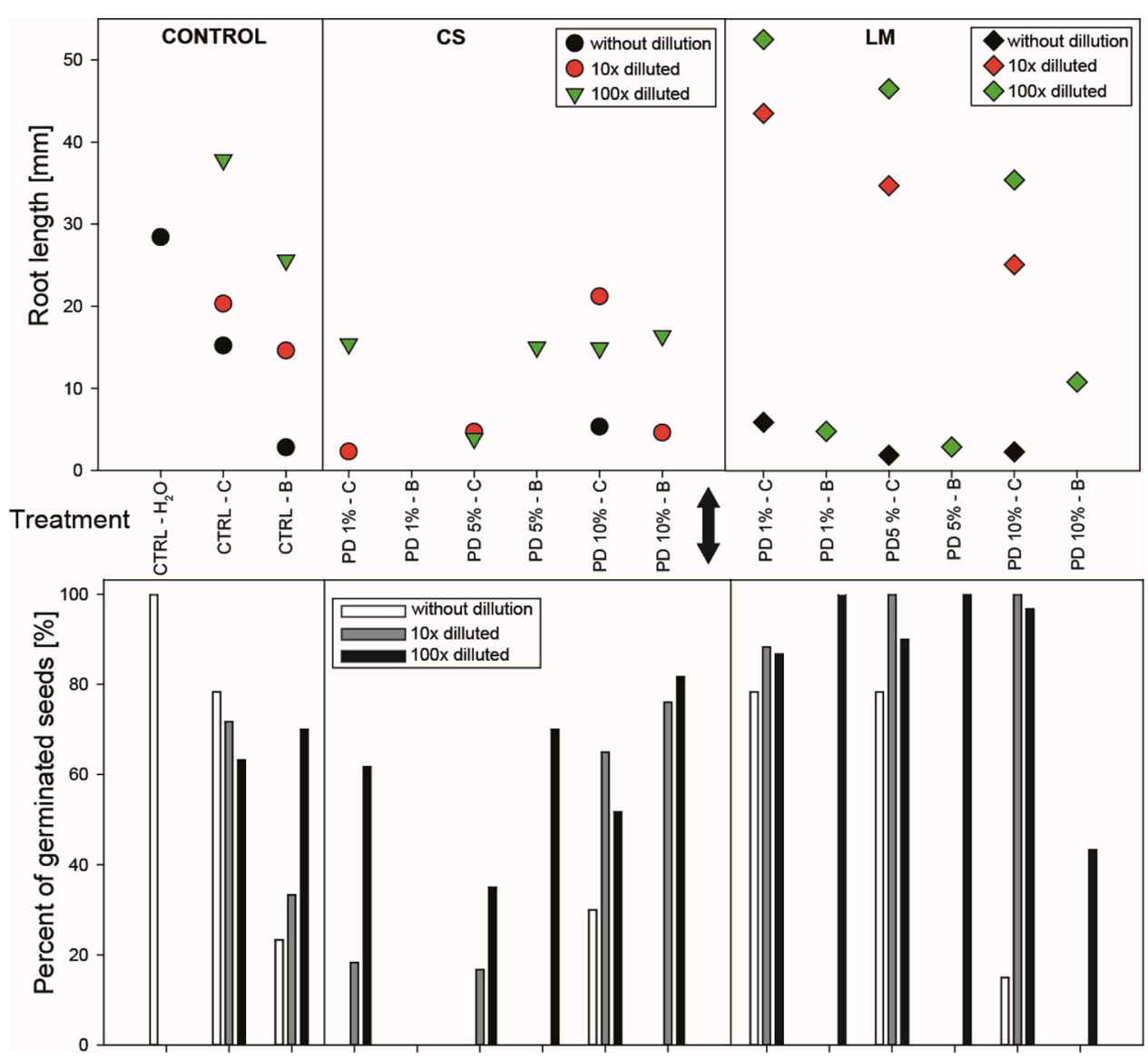

Fig. 6. Germination efficiency (\% of total seeds) and root lengths ( $\mathrm{mm}$ ) developed (C: control treatment with sterile growth medium; B: biotic treatment.

demonstrated that PD ranging from $1-3 \%$ yielded similar extraction efficiencies. The acids used for LM treatment demonstrated the following decreasing efficiency: $\mathrm{HNO}_{3}\left(23,410 \mathrm{mg} \mathrm{kg}^{-1}-64.9 \mathrm{wt} . \%\right)>$ $\mathrm{HCl}\left(17,100 \mathrm{mg} \mathrm{kg}^{-1}-47.4 \mathrm{wt} . \%\right)>\mathrm{H}_{2} \mathrm{SO}_{4}$ (10468 $\mathrm{mg} \mathrm{kg}^{-1}-29.1 \mathrm{wt} \%$ ). In contrast, the maximum efficiency achieved with organic extractants was $2,844 \mathrm{mg} \mathrm{kg}^{-1}-7.9$ wt.\% (1\% PD, oxalic acid). The Cu extraction from CS (Fig. 5) was independent of PD in the range of 1-3\%; additionally, the type of acid played a rather minor role since $\mathrm{Cu}$ extraction was nearly the same for all acids used (with an exception observed for oxalic acid, which was much less efficient). As much as $29,039 \mathrm{mg} \mathrm{kg}^{-1}$ (91.1 wt.\%) was extracted from CS within $24 \mathrm{~h}$ using $\mathrm{HNO}_{3}$ whereas the efficiency of oxalic acid showed a maximum of $4,020 \mathrm{mg} \mathrm{kg}^{-1}$ (12.6 wt. $\%)$. These results confirmed a generally higher susceptibility of $\mathrm{Cu}$ droplets (CS) to dissolve compared to Cu-bearing sulfides (LM). This may be attributed to incorporation of these phases within individual wastes; $\mathrm{Cu}$ droplets (CS) are merged in glass, whereas Cu-sulfides (LM) are hidden between fayalite crystals. Glass is known for its higher susceptibility to dissolution as compared to crystalline phases $[17,38]$ and this behavior of major phases was presumably a deciding factor.

Zinc extraction from LM (Fig. 5) was similar to most studied acids, probably due to the unrestricted access of acids to $\mathrm{Zn}$-bearing sphalerite, with the highest extraction efficiency for $\mathrm{HNO}_{3}$, which has already been reported to influence sphalerite solubility [39]. Zinc leaching from CS (Fig. 5) revealed similar trends to $\mathrm{Cu}$, which means that up to $12,765 \mathrm{mg}$ $\mathrm{kg}^{-1}$ (84.5 wt.\%) of $\mathrm{Zn}$ was extracted within $24 \mathrm{~h}$ using $\mathrm{HNO}_{3}$. Extraction of $\mathrm{Zn}$ with citric acid was $10,089 \mathrm{mg} \mathrm{kg}^{-1}(66.8 \mathrm{wt} \%)$ whereas the efficiency of oxalic acid did not exceed $1,182 \mathrm{mg} \mathrm{kg}^{-1}$ (7.8 wt.\%), suggesting that the latter agent was inefficient.

A comparison of the chemical extraction efficiency achieved in this study with the efficiencies completed by the other similar approaches (Table 2) proves that treatments proposed here are comparingly efficient. Other authors obtained somewhat faster extraction (0.5-4 h, Table 2) yet required thermal treatment (up to $80^{\circ} \mathrm{C}$ ). In our study, leaching duration was longer, but no heating was applied, which is mandatory from energetic viewpoint. Furthermore, optimal acid concentrations suggested by other studies ( 2 to $6 \mathrm{M}$ ) were higher compared to this study (1 to $2 \mathrm{M}$ ). In fact, extraction yield obtained for $\mathrm{Zn}$ was unsatisfactory (max. 8\%), therefore future direction of research dedicated to LM waste could consider following aspects: i) better grinding (smaller particle size), ii) temperature and pressure application, iii) material aging in acid, iv) acid roasting, $v$ ) increase of agitation speed, or vi) repeated leaching cycles.

Biotic extraction succeeded in this study was generally efficient with an exception observed for $\mathrm{Zn}$ that was poorly extracted from LM. Most studies reported a PD of $1-10 \%$ as optimal and often reached quicker extraction rates. This study demonstrated that application of PD $1 \%$ is suitable. However, it is worth to highlight previous treatments involved mixed bacterial cultures instead of single $A$. thiooxidans strain. Therefore, the main prospective to facilitate and improve bioleaching of LM is to use mixed bacterial cultures. For example, application of A. ferroxidans could be beneficial to dissolution of sulfide bearing LM since ferrous iron present in the bioleaching system can be oxidized to ferric iron. The latter oxidize the sphalerite resulting in generation of $\mathrm{Zn}$, ferrous iron and elemental sulfur. Additionally, it has been demonstrated that chemical leaching of sphalerite may be limited by the diffusion of $\mathrm{Fe}^{2+}$ through sulfur layer formed on the surface. This problem can be omitted in the presence of bacteria [32].

\subsection{Toxicity assessment}

Seeds germination in controls (i.e. solutions lacking $\mathrm{Cu}, \mathrm{Zn}$ and $\mathrm{Pb}$ ) revealed following germination rates: $23-70 \%, 63-78 \%$, and $100 \%$, for 
Table 3

Maximum efficiency achieved for selected valuable elements and an estimation of potential economic profit.

\begin{tabular}{|c|c|c|c|c|}
\hline $\begin{array}{l}\text { Element to be } \\
\text { recovered } \\
\text { [Economic value } \\
\text { expressed as } \\
\text { dollars per } \\
\text { kilogram] }\end{array}$ & $\begin{array}{l}\text { Best treatment } \\
\text { found } \\
\text { - chemical } \\
\text { (Chem) } \\
\text { - biotic (Bio) }\end{array}$ & $\begin{array}{l}\text { Treatment } \\
\text { efficiency } \\
\text { [wt.\%] }\end{array}$ & $\begin{array}{l}\text { Amount of } \\
\text { element } \\
\text { extracted } \\
\text { [mg kg-1] }\end{array}$ & $\begin{array}{l}\text { Economic } \\
\text { value } \\
\text { [\$] per } 1 \text { ton } \\
\text { of } \\
\text { the slag } \\
\text { treated }\end{array}$ \\
\hline \multicolumn{5}{|l|}{$\begin{array}{l}\text { Granulated slag } \\
\quad \text { (CS) }\end{array}$} \\
\hline \multirow{2}{*}{$\mathrm{Cu}[5.8]$} & $\begin{array}{l}\text { Chem: } \mathrm{HNO}_{3} \\
2 \% 24 \mathrm{~h}\end{array}$ & 91.1 & 29039 & 167.1 \\
\hline & $\begin{array}{l}\text { Bio: PD 1\%, } 30 \\
\text { days }\end{array}$ & 43.5 & 13874 & 79.8 \\
\hline \multirow{2}{*}{ Zn [2.5] } & $\begin{array}{l}\text { Chem: } \mathrm{HNO}_{3} \\
2 \% 24 \mathrm{~h}\end{array}$ & 84.5 & 12765 & 32.4 \\
\hline & $\begin{array}{l}\text { Bio: PD 1\%, } 30 \\
\text { days }\end{array}$ & 49.9 & 7535 & 19.1 \\
\hline \multirow{2}{*}{$\mathrm{Pb}[2.2]$} & $\begin{array}{l}\text { Chem: } \mathrm{HNO}_{3} \\
2 \% 24 \mathrm{~h}\end{array}$ & 88.3 & 39480 & 86.3 \\
\hline & $\begin{array}{l}\text { Bio: PD 1\%, } 20 \\
\text { days }\end{array}$ & $<1$ & 361 & 0.8 \\
\hline \multirow{2}{*}{ Co $[55.1]$} & $\begin{array}{l}\text { Chem: } \mathrm{HNO}_{3} \\
2 \% 24 \mathrm{~h}\end{array}$ & 78.6 & 1375 & 75.8 \\
\hline & $\begin{array}{l}\text { Bio: PD 1\%, } 30 \\
\text { days }\end{array}$ & 41.2 & 721 & 39.7 \\
\hline \multirow{2}{*}{ Cd [2.8] } & Chem: n.a. & - & - & \\
\hline & Bio: - & - & $<\mathrm{d} .1$ & \\
\hline \multirow{2}{*}{ Mo [24.3] } & $\begin{array}{l}\text { Chem: } \mathrm{HNO}_{3} \\
2 \% 24 \mathrm{~h}\end{array}$ & 91.1 & 656 & 15.9 \\
\hline & $\begin{array}{l}\text { Bio: PD 1\%, } 20 \\
\text { days }\end{array}$ & 91.7 & 661 & 16.0 \\
\hline \multirow[t]{3}{*}{$\operatorname{Cr}[7.2]$} & $\begin{array}{l}\text { Chem: } \mathrm{HNO}_{3} \\
1 \% 24 \mathrm{~h}\end{array}$ & 85.9 & 200 & 1.4 \\
\hline & Bio: n.a & - & - & - \\
\hline & $\begin{array}{l}\text { Chem: } \mathrm{H}_{2} \mathrm{SO}_{4} \\
5 \% 24 \mathrm{~h}\end{array}$ & 79.4 & 549 & 7.7 \\
\hline $\mathrm{Ni}[14.0]$ & $\begin{array}{l}\text { Bio: PD 1\%, } 20 \\
\text { days }\end{array}$ & 79.2 & 547 & 7.7 \\
\hline \multicolumn{5}{|l|}{ Lead matte (LM) } \\
\hline \multirow{2}{*}{$\mathrm{Cu}[5.8]$} & $\begin{array}{l}\text { Chem: } \mathrm{HNO}_{3} \\
2 \% 24 \mathrm{~h}\end{array}$ & 64.9 & 23410 & 134.7 \\
\hline & $\begin{array}{l}\text { Bio: PD } 10 \% \text {, } \\
30 \text { days }\end{array}$ & 69.6 & 25077 & 144.3 \\
\hline \multirow{2}{*}{$\mathrm{Zn}[2.5]$} & $\begin{array}{l}\text { Chem: } \mathrm{HNO}_{3} \\
3 \% 24 \mathrm{~h}\end{array}$ & 7.9 & 15689 & 39.8 \\
\hline & $\begin{array}{l}\text { Bio: PD 5\%, } 30 \\
\text { days }\end{array}$ & 12.0 & 23896 & 60.6 \\
\hline \multirow{2}{*}{$\mathrm{Pb}[2.2]$} & $\begin{array}{l}\text { Chem: } \mathrm{HCl} 1 \% \\
24 \mathrm{~h}\end{array}$ & 71.4 & 39214 & 85.7 \\
\hline & $\begin{array}{l}\text { Bio: PD 1\%, } 30 \\
\text { days }\end{array}$ & $<1 \%$ & 387 & 0.8 \\
\hline \multirow{2}{*}{ Co $[55.1]$} & $\begin{array}{l}\text { Chem: } \mathrm{H}_{2} \mathrm{SO}_{4} \\
2 \% 24 \mathrm{~h}\end{array}$ & 95.8 & 58.0 & 3.2 \\
\hline & $\begin{array}{l}\text { Bio: PD 1\%, } 30 \\
\text { days }\end{array}$ & 56.1 & 33.9 & 1.9 \\
\hline \multirow[b]{2}{*}{ Cd [2.8] } & Chem: n.a. & - & - & 0.4 \\
\hline & $\begin{array}{l}\text { Bio: PD 5\%, } 30 \\
\text { days }\end{array}$ & 10.1 & 135 & \\
\hline \multirow{2}{*}{ Mo [24.3] } & $\begin{array}{l}\text { Chem: } \mathrm{HNO}_{3} \\
1 \% 24 \mathrm{~h}\end{array}$ & 43.6 & 152 & 3.7 \\
\hline & $\begin{array}{l}\text { Bio: PD 1\%, } 30 \\
\text { days }\end{array}$ & 40.4 & 141 & 3.4 \\
\hline \multirow[t]{2}{*}{$\mathrm{Cr}[7.2]$} & $\begin{array}{l}\text { Chem: } \mathrm{H}_{2} \mathrm{SO}_{4} \\
1 \% 24 \mathrm{~h}\end{array}$ & 19.4 & 161 & 1.2 \\
\hline & Bio: n.a & - & - & \\
\hline \multirow{2}{*}{$\mathrm{Ni}[14.0]$} & $\begin{array}{l}\text { Chem: } \mathrm{H}_{2} \mathrm{SO}_{4} \\
3 \% 24 \mathrm{~h}\end{array}$ & 74.1 & 327 & 4.6 \\
\hline & $\begin{array}{l}\text { Bio: PD 1\%, } 20 \\
\text { days }\end{array}$ & 64.7 & 286 & 4.0 \\
\hline
\end{tabular}

*Metal prices available from USGS, www.usgs.gov [49]
B (biotic solution), C (control growth medium) and $\mathrm{H}_{2} \mathrm{O}$ respectively (Fig. 6, Table S1, Supplementary materials). As control solutions were free of metals, the $\mathrm{pH}$ was likely a factor that caused slight inhibition in seeds germination (Fig. 6). The seeds immersed in biotic leachates did not at all germinate presumably due to high metal concentrations. The negative effect of metals on seed germination, root elongation, and biochemical and plant physiological processes is well known [50-53]. In addition, studies devoted to $B$. juncea revealed a lower shoot growth in response to elevated $\mathrm{Cu}$ and $\mathrm{Zn}$ concentrations [54,55]. For this reason, higher germination rates were observed in diluted leachates with lower metal load. An interesting observation from this test is that the seed germination observed in diluted leachates revealed a higher germination in $\mathrm{C}$ as compared to $\mathrm{B}$ solutions. The leachates were enriched with a number of metals and the effects on germination can be both synergistic and antagonistic, thus inhibition cannot be attributed to a certain metal. For example, in LM-C leachates (LM-C containing 1,151 $\mathrm{mg} \mathrm{kg}^{-1}$ ) 2.7 times lower concentrations of $\mathrm{Cu}$ were contained compared to $\mathrm{CS}-\mathrm{C}$ leachates (CS-C 1\% PD; 3,114 $\mathrm{mg} \mathrm{kg}^{-1}$ of $\mathrm{Cu}$ ). As a result the germination rates observed in CS-C were notably lower compared to LS-C. On the other hand, LM-C (1\% PD) was $\sim 1.6$ more concentrated in $\mathrm{Zn}$ compared to $\mathrm{CS}-\mathrm{C}\left(3,578 \mathrm{mg} \mathrm{kg}^{-1}\right)$. Thus, one may carefully suspect $\mathrm{Cu}$ to be a primary factor limiting germination. Furthermore, elevated concentrations of $\mathrm{Al}$ are known to cause toxicity to roots in acidic conditions [56-58]. In this study, $\mathrm{Al}$ leaching from CS-B at 1\% PD was nearly 26, $000 \mathrm{mg} \mathrm{kg}^{-1}$ whereas at the same PD, LM-B only leached $217 \mathrm{mg} \mathrm{kg}^{-1}$. That could be an additional reason for a lower germination in CS-C that that observed in LM-C (Fig. 6, Table S1, Supplementary materials). Despite not allowing to identify single metals responsible for germination inhibition, such test still constitute a rapid and reliable tool to assess potential adverse environmental characteristics as a sum of metal stressors.

\section{Prospective treatments of metallurgical wastes}

The economic viability of the process is a strong driver for the development of a recovery technique [11]. On the other hand, the need for finding secondary metal resources, as established by the EU economy forecast, highlights the importance of developing suitable extracting conditions for metallurgical wastes. The maximum economic potential calculated here (Table 3 ) was based on the average metal prices reported by the US Geological Survey [49]. Elements extracted within $24 \mathrm{~h}$ were taken into account for this estimation because the extension to $48 \mathrm{~h}$ of extraction did not have a major influence on the extraction yield (Fig. 3S, supplementary materials). The maximum economic potential estimated for CS was $\$ 167$ per ton of slag treated whereas for LM this was $\$ 135$ per ton. It must be noted that this value corresponds to the theoretical maximum based on single, high-purity metals. In other words, reported estimates provided here too optimistic being the product of dissolved metal concentration in a mixed leachate times the price of high-purity, single metals. In addition, if any of aforementioned treatments would be applied at industrial scale, the expenses related to process maintenance and selective metal recovery from the leachate will undoubtedly affect the process economy. In these regards, estimates proposed in this study should be concerned as an orientation and comparison to others. For example, [13] took into account some expenses related to maintenance of laboratory bioleaching and found out that economic profit is at the level of 15 euros per ton of slag. Likewise, [59] estimated $\$ 512$ per ton of slag and [60] reported values of $\$ 90(\mathrm{~V})$ and $\$ 160$ ( $\mathrm{Zn}$ ) per ton of slag provided that expenses related to treatment execution will be optimized. Although secondary waste processing is still not well developed, the environmental benefit created by this processing and the resulting generation of metal-depleted residues is a benefit that cannot be easily assessed. 


\section{Concluding remarks}

Metallurgical wastes were susceptible to dissolution in mineral and organic acids as well as to bioleaching, which renders these industrial by-products suitable candidates for $\mathrm{Cu}$ and $\mathrm{Zn}$ extraction/recovery processes. CS was more susceptible to chemical acid dissolution compared to LM. In contrast, LM displayed a greater bioleaching potential at PD 5\% and 10\% compared to CS. From an environmental viewpoint, processing CS may be desirable because it resulted in a solid residue depleted in metals due to gypsum formation. Further process optimization would be required for LM in order to generate a metaldepleted residue, and extending bioleaching times and/or application of mixed bacterial cultures involving $A$. ferrooxidans is a potential way to do this. Based on the amount of base metals extracted, both wastes revealed economic potential (with an assumption of selective recovery) assessed at up to $\$ 167$ (CS) and \$135 (LM), indicating copper is more valuable to recover. The toxicity assessment revealed that metalcharged leachates may cause the inhibition of seed germination and root development, indicating germination test as a rapid and valuable tool for environmental assessment of leachates toxicity.

\section{CRediT authorship contribution statement}

Anna Potysz: Conceptualization, Data curation, Funding acquisition, Investigation, Methodology, Project administration, Visualization, Writing - original draft. Artur Pędziwiatr: Methodology, Visualization, Writing - review \& editing. Sebastian Hedwig: Methodology. Markus Lenz: Methodology, Writing - review \& editing.

\section{Declaration of Competing Interest}

The authors report no declarations of interest.

\section{Acknowledgements}

This work was financially supported by the National Science Centre (NCN) in Poland in the frame of the SONATA program under grant agreement UMO-2018/31/D/ST10/00738 to AP. The authors thank the professional native speaker for proofreading the submitted version of this manuscript. The authors would like to thank anonymous Reviewers and the Editor for their time devoted to evaluating our work and valuable suggestions that helped us to improve quality of the manuscript.

\section{Appendix A. Supplementary data}

Supplementary material related to this article can be found, in the online version, at doi:https://doi.org/10.1016/j.jece.2020.104450.

\section{References}

[1] C.R. Cánovas, S. Chapron, G. Arrachart, S. Pellet-Rostaing, Leaching of rare earth elements (REEs) and impurities from phosphogypsum: A preliminary insight for further recovery of critical raw materials, J. Clean. Prod. (2019), https://doi.org/ 10.1016/j.jclepro.2019.02.104.

[2] K.M. Goodenough, J. Schilling, E. Jonsson, P. Kalvig, N. Charles, J. Tuduri, E. A. Deady, M. Sadeghi, H. Schiellerup, A. Müller, G. Bertrand, N. Arvanitidis, D. G. Eliopoulos, R.A. Shaw, K. Thrane, N. Keulen, Europe's rare earth element resource potential: An overview of REE metallogenetic provinces and their geodynamic setting, Ore Geol. Rev. (2016), https://doi.org/10.1016/j. oregeorev.2015.09.019.

[3] M. Radetzki, Seven thousand years in the service of humanity-the history of copper, the red metal, Resour. Policy. 34 (2009) 176-184, https://doi.org/10.1016/j. resourpol.2009.03.003.

[4] P. Rasoulnia, R. Barthen, A.-M. Lakaniemi, A critical review of bioleaching of rare earth elements: The mechanisms and effect of process parameters, Crit. Rev. Environ. Sci. Technol. (2020), https://doi.org/10.1080/10643389.2020.1727718.

[5] N.T. Arndt, L. Fontboté, J.W. Hedenquist, S.E. Kesler, J.F.H. Thompson, D. G. Wood, Future global mineral resources, Geochemical Perspect. (2017), https:// doi.org/10.7185/geochempersp.6.1.
[6] C. Erüst, A. Akcil, C.S. Gahan, A. Tuncuk, H. Deveci, Biohydrometallurgy of secondary metal resources: A potential alternative approach for metal recovery, J. Chem. Technol. Biotechnol. (2013), https://doi.org/10.1002/jctb.4164.

[7] N. Fomchenko, T. Uvarova, M. Muravyov, Effect of mineral composition of sulfidic polymetallic concentrates on non-ferrous metals bioleaching, Miner. Eng. (2019), https://doi.org/10.1016/j.mineng.2019.04.026.

[8] A.H. Kaksonen, A.M. Lakaniemi, O.H. Tuovinen, Acid and ferric sulfate bioleaching of uranium ores: A review, J. Clean. Prod. (2020), https://doi.org/10.1016/j. jclepro.2020.121586.

[9] European Commision, An EU action plan for the circular economy, Com. (2015), https://doi.org/10.1017/CBO9781107415324.004.

[10] N.M. Piatak, Environmental Characteristics and Utilization Potential of Metallurgical Slag. Environ. Geochemistry Site Charact. Data Anal. Case Hist, Second Ed., 2018, https://doi.org/10.1016/B978-0-444-63763-5.00020-3.

[11] A. Pathak, L. Morrison, M.G. Healy, Catalytic potential of selected metal ions for bioleaching, and potential techno-economic and environmental issues: A critical review, Bioresour. Technol. (2017), https://doi.org/10.1016/j. biortech.2017.01.001.

[12] N.M. Piatak, M.B. Parsons, R.R. Seal, Characteristics and environmental aspects of slag: A review, Appl. Geochemistry. 57 (2015) 236-266, https://doi.org/10.1016/ j.apgeochem.2014.04.009.

[13] A. Potysz, E.D. van Hullebusch, J. Kierczak, Perspectives regarding the use of metallurgical slags as secondary metal resources - A review of bioleaching approaches, J. Environ. Manage. 219 (2018), https://doi.org/10.1016/j. jenvman.2018.04.083.

[14] Z. Guo, L. Zhang, Y. Cheng, X. Xiao, F. Pan, K. Jiang, Effects of pH, pulp density and particle size on solubilization of metals from a $\mathrm{Pb} / \mathrm{Zn}$ smelting slag using indigenous moderate thermophilic bacteria, Hydrometallurgy. (2010), https://doi. org/10.1016/j.hydromet.2010.04.006.

[15] A. Potysz, J. Kierczak, Y. Fuchs, M. Grybos, G. Guibaud, P.N.L. Lens, E.D. van Hullebusch, Characterization and $\mathrm{pH}$-dependent leaching behaviour of historical and modern copper slags, J. Geochemical Explor. 160 (2016), https://doi.org/ 10.1016/j.gexplo.2015.09.017.

[16] Y.G. Liu, M. Zhou, G.M. Zeng, X. Wang, X. Li, T. Fan, W.H. Xu, Bioleaching of heavy metals from mine tailings by indigenous sulfur-oxidizing bacteria: Effects of substrate concentration, Bioresour. Technol. (2008), https://doi.org/10.1016/j. biortech.2007.08.064.

[17] N. Tshiongo, R.K.K. Mbaya, K. Maweja, L.C. Tshabalala, Effect of cooling rate on base metals recovery from copper matte smelting slags, World Acad. Sci. Eng. Technol. (2010).

[18] S.M. Abdel Basir, M.A. Rabah, Hydrometallurgical recovery of metal values from brass melting slag, Hydrometallurgy. (1999), https://doi.org/10.1016/S0304386X(99)00030-4.

[19] J. Che, Y. Chen, B. Ma, C. Wang, W. Zhang, Recovery of metallic Bi from $\mathrm{Pb}$ [sbnd] Bi slag: An integrated process of chloride leaching and electrowinning, Hydrometallurgy. (2020), https://doi.org/10.1016/j.hydromet.2020.105321.

[20] A. Potysz, E.D. van Hullebusch, J. Kierczak, M. Grybos, P.N.L. Lens, G. Guibaud, Copper metallurgical slags - current knowledge and fate: A review, Crit. Rev. Environ. Sci. Technol. 45 (2015), https://doi.org/10.1080/ 10643389.2015.1046769.

[21] M. Di Salvatore, A.M. Carafa, G. Carratù, Assessment of heavy metals phytotoxicity using seed germination and root elongation tests: A comparison of two growth substrates, Chemosphere. (2008), https://doi.org/10.1016/j. chemosphere.2008.07.061.

[22] J. Bae, G. Mercier, A.K. Watson, D.L. Benoit, Seed germination test for heavy metal phytotoxicity assessment, Can. J. Plant Sci. (2014), https://doi.org/10.4141/cjps2014-018.

[23] A. Potysz, A. Pędziwiatr, S. Hedwig, M. Lenz, Rapid metal mobilisation through litter, water and bioweathering as the legacy of historical copper smelting, J. Geochemical Explor. (2019), https://doi.org/10.1016/j.gexplo.2019.106364.

[24] Y. Gao, A.D. Bradshaw, The containment of toxic wastes: II. Metal movement in leachate and drainage at Parc lead-zinc mine, North Wales, Environ. Pollut. (1995), https://doi.org/10.1016/0269-7491(95)00011-F.

[25] B.G. Lottermoser, Mobilization of heavy metals from historical smelting slag dumps, north Queensland, Australia, Mineral. Mag. 66 (2002) 475-490, https:// doi.org/10.1180/0026461026640043.

[26] A. Schippers, W. Sand, Bacterial leaching of metal sulfides proceeds by two indirect mechanisms via thiosulfate or via polysulfides and sulfur, Appl. Environ. Microbiol. (1999), https://doi.org/10.1128/aem.65.1.319-321.1999.

[27] A.H. Kaksonen, S. Särkijärvi, J.A. Puhakka, E. Peuraniemi, S. Junnikkala, O. H. Tuovinen, Chemical and bacterial leaching of metals from a smelter slag in acid solutions, Hydrometallurgy. (2016), https://doi.org/10.1016/j. hydromet.2015.10.032.

[28] A. Potysz, P.N.L. Lens, J. van de Vossenberg, E.R. Rene, M. Grybos, G. Guibaud, J. Kierczak, E.D. van Hullebusch, Comparison of $\mathrm{Cu}, \mathrm{Zn}$ and Fe bioleaching from Cu-metallurgical slags in the presence of Pseudomonas fluorescens and Acidithiobacillus thiooxidans, Appl. Geochemistry. 68 (2016), https://doi.org/ 10.1016/j.apgeochem.2016.03.006.

[29] L.E. Eary, M.A. Williamson, Simulations of the neutralizing capacity of silicate rocks in acid mine drainage environments, 7th Int. Conf. Acid Rock Drain. 2006, ICARD - Also Serves as 23rd Annu. Meet. Am. Soc. Min. Reclam. (2006).

[30] B. Dold, Acid rock drainage prediction: A critical review, J. Geochemical Explor. (2017), https://doi.org/10.1016/j.gexplo.2016.09.014.

[31] H.F. Steger, L.E. Desjardins, Oxidation of sulfide minerals, in: V. Galena (Ed.), sphalerite and chalcocite., Can. Mineral, 1980. 
[32] T.A. Fowler, F.K. Crundwell, Leaching of zinc sulfide by Thiobacillus ferrooxidans: Bacterial oxidation of the sulfur product layer increases the rate of zinc sulfide dissolution at high concentrations of ferrous ions, Appl. Environ. Microbiol. (1999), https://doi.org/10.1128/aem.65.12.5285-5292.1999.

[33] I.M. Ahmed, A.A. Nayl, J.A. Daoud, Leaching and recovery of zinc and copper from brass slag by sulfuric acid, J. Saudi Chem. Soc. (2016), https://doi.org/10.1016/j. jscs.2012.11.003.

[34] A.N. Banza, E. Gock, K. Kongolo, Base metals recovery from copper smelter slag by oxidising leaching and solvent extraction, Hydrometallurgy. 67 (2002) 63-69, https://doi.org/10.1016/S0304-386X(02)00138-X.

[35] A.V. Beşe, O.N. Ata, C. Çelik, S. Çolak, Determination of the optimum conditions of dissolution of copper in converter slag with chlorine gas in aqueous media, Chem. Eng. Process. (2003), https://doi.org/10.1016/S0255-2701(02)00040-5.

[36] D. Pan, L. Li, X. Tian, Y. Wu, N. Cheng, H. Yu, A review on lead slag generation, characteristics, and utilization, Resour. Conserv. Recycl. (2019), https://doi.org/ 10.1016/j.resconrec.2019.03.036.

[37] É. Ujaczki, Y.S. Zimmermann, C.A. Gasser, M. Molnár, V. Feigl, M. Lenz, Red mud as secondary source for critical raw materials - extraction study, J. Chem. Technol. Biotechnol. (2017), https://doi.org/10.1002/jctb.5300.

[38] K. Maweja, T. Mukongo, R.K. Mbaya, E.A. Mochubele, Effect of annealing treatment on the crystallisation and leaching of dumped base metal smelter slags, J. Hazard. Mater. (2010), https://doi.org/10.1016/j.jhazmat.2010.07.023.

[39] P. Peng, H. Xie, L. Lu, Leaching of a sphalerite concentrate with H2SO4-HNO3 solutions in the presence of C2Cl4, Hydrometallurgy. (2005), https://doi.org/ 10.1016/j.hydromet.2005.08.004.

[40] S. Anand, K. Sarveswara Rao, P.K. Jena, Pressure leaching of copper converter slag using dilute sulphuric acid for the extraction of cobalt, nickel and copper values, Hydrometallurgy. (1983), https://doi.org/10.1016/0304-386X(83)90061-0.

[41] G. Shi, Y. Liao, B. Su, Y. Zhang, W. Wang, J. Xi, Kinetics of copper extraction from copper smelting slag by pressure oxidative leaching with sulfuric acid, Sep. Purif. Technol. (2020), https://doi.org/10.1016/j.seppur.2020.116699.

[42] M.K. Khalid, J. Hamuyuni, V. Agarwal, J. Pihlasalo, M. Haapalainen, M. Lundström, Sulfuric acid leaching for capturing value from copper rich converter slag, J. Clean. Prod. (2019), https://doi.org/10.1016/j. jclepro.2019.01.083.

[43] A. Potysz, J. Kierczak, Prospective (Bio)leaching of historical copper slags as an alternative to their disposal, Minerals. (2019), https://doi.org/10.3390/ min9090542.

[44] J. Wang, Q. Huang, T. Li, B. Xin, S. Chen, X. Guo, C. Liu, Y. Li, Bioleaching mechanism of $\mathrm{Zn}, \mathrm{Pb}$, In, $\mathrm{Ag}$, Cd and $\mathrm{As}$ from $\mathrm{Pb} / \mathrm{Zn}$ smelting slag by autotrophic bacteria, J. Environ. Manage. (2015), https://doi.org/10.1016/j. jenvman.2015.05.013.

[45] S. Panda, S. Mishra, D.S. Rao, N. Pradhan, U. Mohapatra, S. Angadi, B.K. Mishra, Extraction of copper from copper slag: Mineralogical insights, physical beneficiation and bioleaching studies, Korean J. Chem. Eng. 32 (2015) 667-676, https://doi.org/10.1007/s11814-014-0298-6.

[46] A.H. Kaksonen, S. Särkijärvi, E. Peuraniemi, S. Junnikkala, J.A. Puhakka, O. H. Tuovinen, Metal biorecovery in acid solutions from a copper smelter slag,
Hydrometallurgy. 168 (2017) 135-140, https://doi.org/10.1016/j. hydromet.2016.08.014.

[47] A. Schippers, Bioleaching of copper slag material, 2017, https://doi.org/10.4028/ www.scientific.net/SSP.262.61.

[48] K.D. Mehta, B.D. Pandey, Premchand, Bio-assisted leaching of copper, nickel and cobalt from copper converter slag, Mater. Trans. JIM. (1999), https://doi.org/ 10.2320/matertrans 1989.40.214.

[49] N.M. Awad, A.A. Abd El-Kader, M. Attia, A.K. Alva, Effects of Nitrogen Fertilization and Soil Inoculation of Sulfur-Oxidizing or Nitrogen-Fixing Bacteria on Onion Plant Growth and Yield, Int. J. Agron. 2011 (2011) 1-6, https://doi.org/10.1155/2011/ 316856.

[50] M. Drab, A. Greinert, J. Kostecki, M. Grzechnik, SEED GERMINATION OF SELECTED PLANTS UNDER THE INFLUENCE OF HEAVY METALS The group of heavy metals are : $\mathrm{Cd}, \mathrm{Cr}, \mathrm{Cu}, \mathrm{Pb}, \mathrm{Hg}, \mathrm{Ni}, \mathrm{Zn}$ [30], although some elements mentioned above, the definition of " heavy metals " is not uniform and (background), Civ. Environ. Engeneering Reports. 7 (2011) 47-57.

[51] A. Fargašová, Phytotoxic effects of $\mathrm{Cd}, \mathrm{Zn}, \mathrm{Pb}, \mathrm{Cu}$, and $\mathrm{Fe}$ on Sinapis alba L. seedlings and their accumulation in roots and shoots, Biol. Plantarium. 44 (3) (2001) 471-473.

[52] M.Z. Iqbal, U. Habiba, S. Nayab, M. Shafiq, Effects of Copper on Seed Germination and Seedling Growth Performance of Lens Culinaris Medik, J. Plant Dev. 25 (2018) 85-90, https://doi.org/10.33628/jpd.2018.25.1.85.

[53] S.K. Sethy, S. Ghosh, Effect of heavy metals on germination of seeds, J. Nat. Sci. Biol. Med. 4 (2013) 272-275, https://doi.org/10.4103/0976-9668.116964.

[54] H.J. Schäfer, S. Greiner, T. Rausch, A. Haag-Kerwer, In seedlings of the heavy metal accumulator Brassica juncea $\mathrm{Cu} 2+$ differentially affects transcript amounts for $\gamma$-glutamylcysteine synthetase ( $\gamma$-ECS) and metallothionein (MT2), FEBS Lett. (1997), https://doi.org/10.1016/S0014-5793(97)00132-4.

[55] G. Feigl, N. Lehotai, Á. Molnár, A. Ördög, M. Rodríguez-Ruiz, J.M. Palma, F. J. Corpas, L. Erdei, Z. Kolbert, Zinc induces distinct changes in the metabolism of reactive oxygen and nitrogen species (ROS and RNS) in the roots of two Brassica species with different sensitivity to zinc stress, Ann. Bot. (2015), https://doi.org/ $10.1093 / \mathrm{aob} / \mathrm{mcu} 246$.

[56] M. Abedi, M. Bartelheimer, P. Poschlod, Aluminium toxic effects on seedling root survival affect plant composition along soil reaction gradients - a case study in dry sandy grasslands, J. Veg. Sci. 24 (2013) 1074-1085, https://doi.org/10.1111/ jvs.12016.

[57] S.K. Panda, F. Baluska, H. Matsumoto, Aluminum stress signaling in plants, Plant Signal. Behav. 4 (2009) 592-597, https://doi.org/10.4161/psb.4.7.8903.

[58] G.R. Rout, S. Samantaray, P. Das, Aluminium toxicity in plants: A review, Agronomie. 21 (2001) 3-21, https://doi.org/10.1051/agro:2001105.

[59] B. Mikoda, A. Potysz, E. Kmiecik, Bacterial leaching of critical metal values from Polish copper metallurgical slags using Acidithiobacillus thiooxidans, J. Environ. Manage. (2019), https://doi.org/10.1016/j.jenvman.2019.02.032.

[60] V. Ettler, A. Jarošíková, M. Mihaljevič, B. Kř́bek, I. Nyambe, F. Kamona, B. Mapani, Vanadium in slags from smelting of African Pb-Zn vanadate ores: Mineralogy, extractability and potential recovery, J. Geo. Explo. (2020), https:// doi.org/10.1016/j.gexplo.2020.106631. 